\title{
УАК 658.336
}

1. О. Чорна,

д.е.н., професор, професор кафедри управління та адміністрування,

Житомирсъкий інститут ПрАТ "ВНЗ "Міжрегіональна академія управління персоналом"

ORCID ID: 0000-0002-8724-9145

O.B. Пішик,

к.e. $\boldsymbol{H}$.

ORCID ID: 0000-0001-7373-0811

O. F. Матяи,

mazicmp

ORCID ID: 0000-0001-8894-7175

\section{ЕВОАЮЦІЙНИЙ РОЗВИТОК УПРАВАІНСЬКОГО ПОТЕНЦІААУ ПІАПРИЕМСТВА}

\author{
L. Chorna, \\ Doctor of Economic Sciences, Professor, Professor of the Department of Management and Administration, \\ Zhytomyr Institute "Interregional Academy of Personnel Management" \\ O. Pishchyk, \\ PhD in EConomics \\ O. Matyash, \\ Master's degree
}

\section{EVOLUTIONARY DEVELOPMENT OF MANAGERIAL POTENTIAL OF THE ENTERPRISE}

Стаття містить результати досліджень еволюційного розвиткУ УПравлінського потенціалУ підприємства відповідно до його життевого цикАу. Реальність господарської діяльності підприємСтв, різноманітні зміни у зовнішньому та внутрішньому середовищі свідчать про те, що кожне підприємство проходить Свій життєвий цикА. Хвилі кризових етапів розвитку підприємства потребують спеціальних процедур оновлення стабільного періоду функціонування підприємСтва залежать віА рівня його управлінського потенціалу. Активний розвиток віртуальних та проєктних організацій свідчить про необхідність запровадження динамічних змін, диверсифікації напряміві розвитку підприємств. Це здійснюється шляхом запровадження різноманітних проєктів. АИя таких ПідприємСтв УПравАінСький Потенціал є основою дАя ї діяльності.

ЕВолюційний розвиток управлінського потенціалу полягає в процесах його розвитку разом 3 розвитком підприємства, процесах адаптації підприємства та його менеджменту на всіх рівнях до ринкових ситуацій, особливостей життєвого цикАу підприємства тощо.

Відомий життевий цикА розвиткУ підприемства ві,Аносно управАінського потенціалуможе бути предСтавлений за такими етапами: зародження, створення, зростання,

На етапі зародження виявляються можливості управлінського потенціалу персоналу підприємства та необхідні ресурсні та під тримуючі скАадові для розвитку управлінського потенціалу. Серед них інноваційна та інформаційна СкАадові, корпоративна культура, наявність ресурсів дия виробництва товарів та послуг.

Крім бюрократичних процедур реєстрації підприемства на етапі створення, необхідно сформувати місію організації, систему комунікацій, структури організації, системуцінностей та мотивації управАіння.

Етап зростання передбачає формування сучасної організаційної структури управління, активного розвитку рівня управлінських навичок у кожного з фахівців, ефективне делегування повноважень, за- 


\section{ЕКОНОМІЧНА НАУКА}

провадження інновацій, активний розвиток корпоративної культури та запровадження сучасного інструментарію дия цифрових комунікацій, роботи в онлайновому середовищі, підтримки процесів прийняття управлінських рішень.

Стабільний етап розвитку підприємства на етапі зрілості передбачає стабільний прибуток, працюють Системи планування, контролю, мотивації, здійснюеться,диверсифікація діяльності, постійний моніторинг конкурентної позиції на ринку тощо.

Етап спаду передбачає зменшення прибутку (або наявність збитків), наявність кризових ситуацій, невідповідність місії, цінностей потребам споживачів та цінностям управлінської команди, застаріле обладнання та інформаційна під тримка тощо.

Різноманітні Підходи, Ао трактування життевого цикАу передбачають використання різноманітного інструментарію дия зменшення ризиків кризових ситуацій. Розвиток управлінського потенціалуможе бути розглянутий як розвиток внутрішнього підприемництва Аля підвищення ефективності діяльності. Етап управління якістю передбачає запровадження системи управління якістю відповідно до всіх бізнеспроцесів. Розвиток управлінського потенціал у підприємства передбачає активний розвиток потенціалу персоналу (професійне та особисте навчання, ініціативи, активні комунікації, інноваційні методи управАіння); запровадження інновацій; автоматизація бізнес-процесів з моніторингом та контролем шляхом інтеграції інформаційної екосистеми та системи управління якістю. Вихід із кризових ситуацій дяя підприємства може бути у вигляді оновлення напрямів діяльності або банкрутства та Аіквідації підприємСтва. УПравлінський потенціал підприемства на кожному етапі житТєвого циклУ підприємСтва має Свій рівень розвитку і повинен відповідати особливостям розвитку підприємСтва, його зовнішньому та внутрішньому середовищу. СУчасними формами підприємств з високим рівнем управлінського потенціалує віртуальні підприємствата проєктні організації.

The article contains the results of research on the evolutionary development of the managerial potential of the enterprise in accordance with its life cycle. The reality of economic activity of enterprises, various changes in the external and internal environment indicate that each enterprise goes through its life cycle. Waves of crisis stages of enterprise development require special procedures to update the stable period of operation of the enterprise depend on the level of its management potential. The active development of virtual and design organizations indicates the need for dynamic change, diversification in the direction of enterprise development. This is done through the implementation of various projects. For such enterprises, management capacity is the basis for their activities.

The evolutionary development of managerial potential consists in the processes of its development together with the development of the enterprise, the processes of adaptation of the enterprise and its management at all levels to market situations, the peculiarities of the life cycle of the enterprise and so on.

The known life cycle of the enterprise in relation to management potential can be represented at the following stages: origin, creation, growth,

At the stage of origin, the possibilities of managerial potential of the enterprise staff and the necessary resource and support components for the development of managerial potential are revealed. Among them are innovation and information components, corporate culture, availability of resources for the production of goods and services.

In addition to the bureaucratic procedures of enterprise registration at the stage of creation, it is necessary to form the mission of the organization, the system of communications, the structure of the organization, the system of values and motivation of management.

The growth stage involves the formation of a modern organizational structure of management, active development of management skills of each specialist, effective delegation of powers, innovation, active development of corporate culture and introduction of modern tools for digital communications, online work, support for management decision-making processes.

The stable stage of enterprise development at the stage of maturity provides a stable profit, operating systems of planning, control, motivation, diversification of activities, constant monitoring of the competitive position in the market and more.

The recession phase involves a decrease in profits (or losses), the presence of crisis situations, the mismatch of mission, values to the needs of consumers and the values of the management team, outdated equipment and information support, and so on.

Different approaches to the interpretation of the life cycle involve the use of various tools to reduce the risk of crisis situations. The development of managerial capacity can be seen as the development of internal entrepreneurship to improve efficiency. The quality management stage involves the introduction of a quality management system in accordance with all business processes. The development of managerial potential of the enterprise involves the active development of staff potential (professional and personal training, initiatives, active communication, innovative management methods); introduction of innovations; automation of business processes with monitoring and control through the integration of information ecosystem and quality management system. The way out of crisis situations for the company can be in the form of renewal of activities or bankruptcy and 
liquidation of the company. The managerial potential of the enterprise at each stage of the life cycle of the enterprise has its own level of development and must correspond to the peculiarities of the development of the enterprise, its external and internal environment. Modern forms of enterprises with a high level of management potential are virtual enterprises and design organizations.

Ключові слова: управлінський потенчіал підприємства; потениіал управлінського персоналу; потенчіал системи управління; потенчіал інфраструктури управління; иифрровий потенчіал управління, еволючійнии розвиток управління.

Key words: managerial potential of the enterprise; potential of management staff; management system potential; potential of management infrastructure; digital potential of management, evolutionary development of management.

\section{ПОСТАНОВКА ПРОБЛЕМИ}

Актуальність питання досліджень розвитку управлінського потенціалу підприємства полягає в гіпотезі кожного власника та топменеджера підприємства, що напрями його діяльності повинні привести до успіху. Aле реальність господарської діяльності підприємств, різноманітні зміни у зовнішньому та внутрішньому середовищі свідчать про те, що кожне підприємство проходить свій життєвий цикл з хвилями кризових ситуацій та періодів і процеси відтворення стабільного періоду функціонування підприємства залежать від рівня його управлінського потенціалу. Сьогодні активно розвиваються проєктні організації, які працюють як підприємства різних напрямів діяльності, запроваджуючи різноманітні проєкти шляхом знаходження та інтеграції інших підприємств, проєктних команд, окремих фахівців. Аля таких підприємств управлінський потенціал $€$ основою для ї діяльності і він має особливості щодо розвитку проєктних команд, сучасних методологій управління, інформаційна підтримка тощо.

\section{АНАЛІЗ РЕЗУЛЬТАТІВ ДОСЛІДЖЕНЬ}

Аналіз результатів досліджень розвитку управлінського потенціалу представлені в низці наукових праць таких авторів: І.Ансофф [1], П. Арукер [2], М. Мелоун, К. Нордстрем, М. Портер [3], О. Тайіті [4] та інші.

Серед українських науковців можна виділити роботи таких авторів: В.Я. Маречик [5], Н.Г. Калюжна [6], Сіменко [7] та інші. Частіше всього автори розглядають управлінський потенціал як потенціал управлінського персоналу та наявність необхідних ресурсів. Але випадки банкрутства підприємств, що були створені успішною командою менеджерів за умови наявності потужної ресурсної бази свідчать про те, що на різних етапах розвитку підприємства управлінський потенціал може бути оцінений за різними рівнями і повинен відповідати різним умовам та потребам розвитку.

\section{МЕТА ДОСЛІДЖЕННЯ}

Мета досліджень - виявити особливості еволюційного розвитку управлінського потенціалу підприємства.

\section{ВИКЛАД ОСНОВНОГО MATEPIAЛY}

Еволюційний розвиток управлінського потенціалу полягає в процесах його розвитку разом з розвитком підприємства. Навіть коли підприємство створено командою, яка має високий рівень потенціалу управлінсь- кого персоналу як на рівні окремих менеджерів, так і на рівні команди, розвиток управлінського потенціалу полягає у процесах адаптації підприємства та його менеджменту на всіх рівнях до ринкових ситуацій, особливостей життєвого циклу підприємства тощо.

Відомий життєвий цикл розвитку підприємства відносно управлінського потенціалу може бути представлений за такими етапами:

1. Етап зародження може бути реалізований одним або командою власників, які мають або шукають інвестиції під власну ідею виробництва або/і послуг, визначають цілі, продукти та послуги, необхідні ресурси. На цьому етапі виявляються можливості управлінського потенціалу персоналу підприємства та необхідні ресурсні та підтримуючі складові для розвитку управлінського потенціалу. Серед них інноваційна та інформаційна складові, корпоративна культура, наявність ресурсів для виробництва товарів та послуг.

2. Етап створення. Крім бюрократичних процедур реєстрації підприємства, необхідно сформувати місію організації, систему комунікацій, структури організації, систему цінностей та мотивації управління. Цей період, як правило передбачає директивний стиль управління. При створенні місії та цінностей підприємство ідеальною ситуацією $є$ аналіз цінностей управлінського персоналу для максимально можливої відповідності цінностей управлінської команди та підприємства. Якщо на цьому етапі працює лідерська управлінська команда, яка $€$ автором створення підприємства, головної ідеї його функціонування, то це, як правило свідчить про зіставлення цінностей.

3. Етап зростання передбачає формування сучасної організаційної структури управління, активного розвитку рівня управлінських навичок у кожного з фахівців, ефективне делегування повноважень, запровадження інновацій, активний розвиток корпоративної культури та запровадження сучасного інструментарію для цифрових комунікацій, роботи в онлайновому середовищі, підтримки процесів прийняття управлінських рішень. На цьому етапі управлінський персонал повинен мати високий рівень навичок делегування та комунікацій, запровадження змін на основі глибокого аналізу ринкових та виробничих ситуацій, звітності, прогнозування розвитку тощо.

4. Етап зрілості. Стабільний етап розвитку підприємства, на якому є стабільний прибуток, працюють системи планування, контролю, мотивації, здійснюється диверсифікація діяльності, постійний моніторинг конкурентної позиції на ринку тощо. Такий етап передбачає активну аналітичну інформаційну підтримку для прийняття управлінських рішень. 
Таблиця 1. Стадії розвитку управлінського потенціалу підприємства за етапами життєвого циклу від дитинства до ранньої зрілості

\begin{tabular}{|c|c|c|c|c|}
\hline $\begin{array}{c}\text { Управлінські } \\
\text { команди } \\
\text { створення } \\
\text { підприємства }\end{array}$ & Народження & Дитинство & Отроцтво & Рання зрілість \\
\hline $\begin{array}{l}\text { Досвідчена } \\
\text { команда } \\
\text { управлінців } 3 \\
\text { наявними } \\
\text { ресурсами /без } \\
\text { наявних } \\
\text { ресурсів }\end{array}$ & $\begin{array}{l}\text { Створює } \\
\text { підприємство } \\
\text { відповідно до } \\
\text { ринкової ситуації, } \\
\text { вкладаючи грошові } \\
\text { та інші ресурси для } \\
\text { позиціонування на } \\
\text { ринку. / Пошук } \\
\text { інвестора з } \\
\text { використанням } \\
\text { власного досвіду } \\
\text { попередніх } \\
\text { успішних проектів }\end{array}$ & $\begin{array}{l}\text { Отримує } \\
\text { короткостроковий } \\
\text { прибуток, який } \\
\text { вкладає для адаптації } \\
\text { та подальшого } \\
\text { зростання, } \\
\text { концентруючи увагу } \\
\text { на конкурентних } \\
\text { позиціях / Інвестиції } \\
\text { для розвитку }\end{array}$ & $\begin{array}{l}\text { Прискорене } \\
\text { зростання } \\
\text { прибутку, } \\
\text { розвиток } \\
\text { додаткових } \\
\text { ринкових ніш, } \\
\text { оновлення місії та } \\
\text { цінностей } \\
\text { /Часткова } \\
\text { окупність } \\
\text { інвестицій }\end{array}$ & $\begin{array}{l}\text { Систематичне зростання } \\
\text { прибутку, свідоме } \\
\text { розуміння місії, цілей та } \\
\text { цінностей, диверсифікація } \\
\text { діяльності, регулярне } \\
\text { навчання персоналу, } \\
\text { активне використання } \\
\text { інструментарію } \\
\text { інформаційної, } \\
\text { інноваційної та } \\
\text { корпоративної складових / } \\
\text { Окупність інвестицій, } \\
\text { можливості використання } \\
\text { внутрішніх інвестицій для } \\
\text { розвитку управлінського } \\
\text { потенціалу }\end{array}$ \\
\hline $\begin{array}{l}\text { Команда } \\
\text { початківців } 3 \\
\text { наявними } \\
\text { ресурсами /без } \\
\text { наявних } \\
\text { ресурсів }\end{array}$ & $\begin{array}{l}\text { Створює } \\
\text { підприємство } \\
\text { відповідно до ідеї } \\
\text { підключаючи } \\
\text { консультантів для } \\
\text { аналізу ринкової } \\
\text { ситуації, } \\
\text { вкладаючи грошові } \\
\text { та інші ресурси для } \\
\text { позиціонування на } \\
\text { ринку. / Пошук } \\
\text { інвестора }\end{array}$ & $\begin{array}{l}\text { Отримує } \\
\text { короткостроковий } \\
\text { прибуток, який } \\
\text { використовується } \\
\text { для забезпечення } \\
\text { команди } \\
\text { консультантів та } \\
\text { підтримки } \\
\text { виробництва товарів } \\
\text { та послуг для } \\
\text { подальшого } \\
\text { зростання, } \\
\text { концентруючи увагу } \\
\text { на конкурентних } \\
\text { позиціях / Інвестиції } \\
\text { для розвитку }\end{array}$ & $\begin{array}{l}\text { Прискорене } \\
\text { зростання } \\
\text { прибутку, } \\
\text { розвиток } \\
\text { додаткових } \\
\text { ринкових ніш, } \\
\text { оновлення місії та } \\
\text { цінностей за } \\
\text { допомогою } \\
\text { команди } \\
\text { консультантів та } \\
\text { активне навчання } \\
\text { персоналу } \\
\text { управління } \\
\text { /Часткова } \\
\text { окупність } \\
\text { інвестицій }\end{array}$ & $\begin{array}{l}\text { Систематичне зростання } \\
\text { прибутку, свідоме } \\
\text { розуміння місії, цілей та } \\
\text { цінностей, } \\
\text { диверсифікація } \\
\text { діяльності за допомогою } \\
\text { команди консультантів, } \\
\text { регулярне навчання } \\
\text { персоналу, активне } \\
\text { використання } \\
\text { інструментарію } \\
\text { інформаційної, } \\
\text { інноваційної та } \\
\text { корпоративної складових } \\
\text { / Окупність інвестицій, } \\
\text { можливості використання } \\
\text { внутрішніх інвестицій } \\
\text { для розвитку } \\
\text { управлінського } \\
\text { потенціалу }\end{array}$ \\
\hline
\end{tabular}

5. Етап спаду передбачає зменшення прибутку (або наявність збитків), наявність кризових ситуацій, невідповідність місії, цінностей потребам споживачів та цінностям управлінської команди, застаріле обладнання та інформаційна підтримка тощо. Такий етап потребує оновлення місії, розробки нової стратегії для відродження. Управлінський потенціал персоналу базується на антикризових навичках та можливостей виходу з кризових ситуацій.

У таблиці 1 представлено особливості розвитку управлінського потенціалу підприємства за такими стадіями, як народження, дитинство, отроцтво, рання зрілість, розквіт. Розвиток управлінського потенціалу відповідно до цих стадій може здійснюватись за двома напрямами:

1. Управлінська команда має високий рівень знань та практичного досвіду; може мати власні ресурсні можливості для розвитку або шукати інвестора. Успіх залучення інвестора полягає у інформованості суспільства щодо попердніх проєктів команди, її успіху в роботі з іншими підприємствами тощо. У випадку створення підприємства на основі інших успішних підприємств, інвестування здійснюється за рахунок підприємствазасновника.

2. Управлінська команда не має досвіду та ресурсів для розвитку і розвивається разом із підприємством. Позитивні моменти такого розвитку, як правило, полягають у ентузіазмі молодої команди, наявності великого обсягу ідей, зіставлення цінностей в команді та відповідно у новоствореного підприємства. Негативні моменти щодо відсутності досвіду можуть привести до небезпечних кризових ситуацій в періоди народження, дитин- ства та отроцтво. Саме тому доцільно сформувати команду досвідчених консультантів, що стануть гарантом за умови пошуку інвестицій та поєднувати власний ентузіазм 3 досвідом управлінської консультативної команди.

Таке балансування сприяє також розвитку управлінського потенціалу за умови запровадження коучінгу, навчання персоналу консультантами, активного розвитку новоствореного підприємства, запровадження інновацій, розвитку корпоративної культури та соціальної відповідальності. На етапах від розквіту сил до оновлення підприємство, як правило, працює приблизно однаково як для досвідченої команди, так і у випадку, коли управління здійснюють початківці, і має власні внутрішні інвестиції для розвитку.

Різноманітні підходи до трактування життєвого циклу передбачають використання різноманітного інструментарію для зменшення ризиків кризових ситуацій. Так, розвиток управлінського потенціалу може бути розглянутий як розвиток внутрішнього підприємництва для підвищення ефективності діяльності. Такий підхід передбачає активне запровадження ініціативи управлінського потенціалу, оновлення стратегії розвитку підприємства і продовжується етапом управління якістю, на якому підприємство запроваджує систему управління якістю відповідно до всіх бізнес-процесів, охоплює всіх учасників управління та акцентує увагу на можливих кризових ситуаціях. Розвиток управлінського потенціалу підприємства передбачає активний розвиток потенціалу персоналу (професійне та особисте навчання, ініціативи, активні комунікації, інноваційні методи управління; запровадження інновацій; автоматизація бізнес-процесів з моніторингом та контролем шля- 
Таблиця 2. Стадії розвитку управлінського потенціалу підприємства за етапами життєвого циклу від дитинства до ранньої зрілості

\begin{tabular}{|c|c|c|c|c|}
\hline $\begin{array}{c}\text { Рівень } \\
\text { кризових } \\
\text { ситуацій }\end{array}$ & Розквіт сил & $\begin{array}{c}\text { Повна } \\
\text { зрілість }\end{array}$ & Старіння & Оновлення \\
\hline $\begin{array}{l}\text { Кризові } \\
\text { ситуації, що } \\
\text { можуть бути } \\
\text { вирішені } \\
\text { управлінською } \\
\text { командою }\end{array}$ & $\begin{array}{l}\text { Збалансоване } \\
\text { функціонування } \\
\text { підприємства, } \\
\text { корпоративне управління } \\
\text { відповідно до цінностей, } \\
\text { регулярне оновлення } \\
\text { знань та навичок } \\
\text { управлінського } \\
\text { персоналу, постійна } \\
\text { інформаційна підтримка } \\
\text { для прийняття } \\
\text { управлінських рішень, } \\
\text { запровадження сучасних } \\
\text { методів управління / } \\
\text { використання внутрішніх } \\
\text { інвестицій для розвитку } \\
\text { управлінського } \\
\text { потенціалу, розвиток } \\
\text { соціальної } \\
\text { відповідальності }\end{array}$ & $\begin{array}{l}\text { Збалансований } \\
\text { розвиток } \\
\text { підприємства } 3 \\
\text { високим } \\
\text { рівнем } \\
\text { корпоративної } \\
\text { культури та } \\
\text { соціальної } \\
\text { відповідальніс } \\
\text { тю, активні } \\
\text { інвестиції в } \\
\text { розвиток } \\
\text { управлінського } \\
\text { потенціалу та } \\
\text { інструментарі } \\
\text { ю підтримки } \\
\text { управлінських } \\
\text { рішень }\end{array}$ & $\begin{array}{l}\text { Зменшення } \\
\text { прибутку, } \\
\text { недостатність } \\
\text { диверсифікація } \\
\text { напрямів, рівня } \\
\text { позиціонування } \\
\text { на ринку, } \\
\text { потреба у } \\
\text { запровадженні } \\
\text { змін для } \\
\text { оновлення за } \\
\text { рахунок } \\
\text { внутрішніх } \\
\text { інвестицій }\end{array}$ & $\begin{array}{l}\text { Систематичне } \\
\text { зростання прибутку, } \\
\text { свідоме розуміння } \\
\text { місії, цілей та } \\
\text { цінностей, } \\
\text { диверсифікація } \\
\text { діяльності, регулярне } \\
\text { навчання персоналу, } \\
\text { активне } \\
\text { використання } \\
\text { інструментарію } \\
\text { інформаційної, } \\
\text { інноваційної та } \\
\text { корпоративної } \\
\text { складових / } \\
\text { Окупність } \\
\text { інвестицій, } \\
\text { можливості } \\
\text { використання } \\
\text { внутрішніх } \\
\text { інвестицій для } \\
\text { розвитку } \\
\text { управлінського } \\
\text { потенціалу }\end{array}$ \\
\hline $\begin{array}{l}\text { Кризові форс- } \\
\text { мажорні } \\
\text { ситуації }\end{array}$ & \multicolumn{2}{|c|}{$\begin{array}{l}\text { Зменшення прибутку та недостатня } \\
\text { рівновага у збалансованому розвитку } \\
\text { підприємства, потреба у кризовому } \\
\text { менеджменті для підтримки } \\
\text { збалансованого зростання }\end{array}$} & $\begin{array}{l}\text { Банкрутство } \\
\text { підприємства та } \\
\text { його ліквідація } \\
\text { або перехід до } \\
\text { оновлення }\end{array}$ & $\begin{array}{l}\text { Відродження } \\
\text { підприємства за } \\
\text { допомогою } \\
\text { кризового } \\
\text { менеджменту }\end{array}$ \\
\hline
\end{tabular}

хом інтеграції інформаційної екосистеми та системи управління якістю.

\section{ВИСНОВКИ}

Кожне підприємство має традиційні етапи життєвого циклу та особливості реалізації процесів відтворення. Вихід із кризових ситуацій для підприємства може бути у вигляді оновлення напрямів діяльності або банкрутства та ліквідації підприємства. Управлінський потенціал підприємства на кожному етапі життєвого циклу підприємства має свій рівень розвитку і повинен відповідати особливостям розвитку підприємства, його зовнішньому та внутрішньому середовищу. Одною із складових управлінського потенціалу є його інноваційна складова, яка повинна бути активною на етапі виявлення перших ознак спаду життєвого циклу розвитку підприємства. Її активізація дозволяє запровадити інноваційні продукти для виробництва та продажу, внести зміни в структурну організацію підприємства та його систему управління. Підтримкою розвитку управлінського потенціалу в цифровій економіці є сучасні інформаційні екосистеми та корпоративна культура підприємства. Сучасними формами підприємств 3 високим рівнем управлінського потенціалу є віртуальні підприємства, проєктні організації.

\section{$\Lambda$ ітература:}

1. Ансофф И. Стратегическое управление. М.: Экономика. 1989, 303 с.

2. Арукер Питер Ф. Менеджмент. Вызовы ХХІ века. М.: Манн, Иванов и Фербер, 2012.256 с.

3. Портер Е. Майкл. Конкурентная стратегия: Методика анализа отраслей и конкурентов / пер. с англ. М.: Альпина Бизнес Букс, 2005. 454 с.

4. Тайити Оно. Производственная система Тойоты. Уходя от массового производства. М.: Институт комплексных стратегических исследований, 2005. 192 с.

5. Маречик В. Я., Невмержицька С. М.Розвиток управлінського потенціалу як запорука успішного функціо- нування підприємства. Вісник Хмельницького національного університету. 2013. № 3. Т. 2. С. 237-242.

6. Калюжна Н.Г. Потенціал системи управління підприємством: сутність і складові елементи. Науковий вісник Полтавського університету економіки і торгівлі. 2011. № 6 (51). Ч. 1. С. 197-211.

7. Сіменко I.B., Романюк М.К. Сутність і основні складові управлінського потенціалу суб'єкту господарювання. Актуальні проблеми економіки. 2012. № 8 (134). C. 209-217.

\section{References:}

1. Ansoff, I. (1989), Strategicheskoe upravlenie [Strategic management], Ekonomika, Moscow, Russia.

2. Druker, P. F. (2012), Menedzhment. Vyizovyi XXI veka [Management. 21st century challenges], Mann, Ivanov i Ferber, Moscow, Russia.

3. Porter, E. M. (2005), Konkurentnaya strategiya: Metodika analiza otraslej i konkurentov [Competitive strategy: Methodology for analyzing industries and competitors], Alpina Pablisher, Moscow, Russia.

4. Tajiti, O. (2005), Proizvodstvennaya sistema Tojoty. Uhodya ot massovogo proizvodstva [Toyota production system. Moving away from mass production], Institute for Integrated Strategic Studies, Moscow, Russia.

5. Marechik, V.Ya. and Nevmerzhic'ka, S.M. (2013), "Development of managerial capacity as a guarantee of successful operation of the enterprise", Visnyk Khmelnytskoho natsionalnoho universytetu, vol. 3, no. 1, pp. 237242.

6. Kaliuzhna, N.H. (2011), "The potential of the enterprise management system: the essence and components", Naukovyi visnyk Poltavskoho universytetu ekonomiky i torhivli, vol. 6, no. 1, pp. 197-211.

7. Simenko I. V. and Romaniuk, M. K. (2012), "The essence and main components of the management potential of the entity", Hlobalni ta natsionalni problemy ekonomiky, vol. 8 (134), pp. $209-217$.

Стаття надійшла до редакиї 07.03.2021 p. 